\title{
Traditional pig rearing practices among the Nicobari tribes of Nicobar group of Islands, India
}

\author{
S. Jeyakumar*, Jai Sunder, M.S. Kundu, A. Kundu and T.P. Swapna ${ }^{1}$ \\ Division of Animal Science Central Island Agricultural Research Insitutte Port Blair - 744 101, Andaman and \\ Nicobar Islands, India \\ *Senior scientist, NDRI-SRS, Adugodi,Bangalore-560 030, ${ }^{1}$ Project Fellow
}

\begin{abstract}
The Andaman \& Nicobar Islands are a group of 572 big and small Islands \& Islets in the South Eastern part of Bay of Bengal. Nicobari pigs (Sus scrofa Nicobaricus) which are indigenous to these islands got domesticated and well adapted to the island ecosystem. A study was conducted on pig rearing system among the Nicobari tribes of Nicobar group of islands viz. Car Nicobar, Katchal, Nancowry, Kamorta, and Teressa. Results of the current study revealed that the Nicobari pigs were reared under traditional system by the Nicobari tribal community and the pigs were concentrated only in Nicobar group of islands. The pigs were reared and considered as family asset among the tribal. The phenotypic characters showed that the Nicobari pigs were indigenous to these islands and their existence was noted since many centuries. These pigs were reared under free range system. Nicobari tribes use various indigenously made materials/utensils for housing and feeding. Pigs were fed mainly with coconut and other locally available feed resources and in addition, pigs feed through scavenging and rooting. No commercial farms or sale of meat was practiced. It is concluded that the Nicobari pigs are considered as an indigenous pig germplasm (Sus scrofa Nicobaricus) belonging to this island territory and Nicobari tribes practices century old established indigenous technical knowledge in pig rearing and they are passed through many generations. ITK would significantly contribute to the generation and pave the way for exploitation of technology to benefit tribal/rural populations.
\end{abstract}

Keywords: Nicobari pig, Traditional rearing practices, Nicobari tribes, Nicobar Islands

\section{Introduction}

The Andaman and Nicobar group of Islands are situated about $1200 \mathrm{~km}$ away from mainland, India in the Bay of Bengal. They form an arched string of about 572 islands, islets and rocks stretching from Burma in the north to Sumatra in the south between $6^{\circ}$ and $14^{\circ}$ North latitudes and $92^{\circ}$ and $94^{\circ}$ East longitudes. They are summits of a submarine range of mountains connecting Arrakkan Yoma of Burma in the North and Pegungan Barrisan of Sumatra in the South enclosing the deep Andaman Sea between this archipelago and Malayan peninsula. Geographically these islands are distinguished in to two groups, i.e. the Andaman group and Nicobar group, separated by $10^{\circ} \mathrm{N}$ channel. The total land area of all these islands amounts to only about $8249 \mathrm{sq} . \mathrm{km}$ of which about 86 percent is covered by lush green tropical rain forests. These islands have a typical maritime climate and are endowed with both Southwest and Northeast monsoons with an average rainfall of $3100 \mathrm{~mm}$ distributed over 8 months (April to November). The native of these islands in the true sense are the primitive tribes of which only Nicobarese are in large numbers. Other tribes include Great Andamanese, Onges, Jarawas, Sentinelese, and Shompens are in very small numbers and they are classified as Particularly Vulnerable Tribal Groups (PTGs). They are essentially hunters and gatherers. All the tribal groups in the A\&N Islands are in areas covered by the A\&N Islands (Protection of Aboriginal Tribes) Regulation, 1956. The tribal population of A\&N Islands as per 2001 census is 29469 , which is 8.27 per cent of total population (1).

The geological isolation makes this group of islands as unique and is endowed with the pristine floral and faunal biodiversity. Among the indigenous livestock germplasm, pig occupies major share among the tribes of Nicobar group of islands. Pigs are part of the Nicobari community's traditions and culture. It is an accepted fact that pig production and pork consumption is strongly associated with tribal (ST) communities particularly in the North-Eastern hill region and piggery is invariably a small-scale backyard enterprise. Traditional management continues to dominate production system with exception that indigenous pigs were largely replaced by crossbreds (2). The pigs which are found in this region are endemic and still in the process of domestication as evidenced by phenotypic appearance and are believed to have an origin from Sus scrofa (Eurasian wild boar) and Nicobaricus as region specific sub species and they are generally called as 'Nicobari Pig'. The Nicobari pigs are present since time immemorial with the primitive tribes of inhabited islands. The present study reports on the traditional pig rearing practices of Nicobari tribes. 


\section{Methodology}

\section{Study area}

\section{Location, topography and climate}

The topography of Andaman and Nicobar Islands (A\&N islands) appears to be a north-south arc, situated between the $16^{\circ}$ and $14^{\circ}$ latitude, and $92^{\circ}$ and $94^{\circ}$ East longitudes. The topography of Andaman and Nicobar Islands is, geologically, a part of land mass of South-east Asia, including Malaysia, North-east India, Burma, Thailand and Indonesia. The Andaman and Nicobar Islands can be broadly divided into two groups viz. Andaman and Nicobar group. These two groups are separated by $10^{\circ}$ Channel which is about $150 \mathrm{~km}$ wide and 400 fathoms deep. The Andaman group consists of 324 islands of which only 20 are inhabited. The total area of Nicobar group is $1841 \mathrm{Sq}$. Km which lies between $6^{0}$ to $10^{\circ}$ North latitude and it comprises of 19 islands of which important are Car Nicobar, Chowra, Teressa, Nancowrie, Little Nicobar and Great Nicobar (3). The islands are fertile, hold a series of ridges and mountains, with moderate elevation and slope with sparse flat lands and are covered with dense tropical rain forest with cluster of coconut palms. The major agricultural activity of the Nicobari tribes revolves around coconut plantation, copra export and fishing. The Government of India declared Nicobar Islands as Aboriginal Tribal Reserve Area. The breeding tract of Nicobari pig is confined to Nicobar group of islands and is reared by the Nicobari communities located in these islands and a small population of Nicobari pig is reared by Nicobari tribes at Little Andaman (Nicobari tribal settlement at Harminder Bay) island (4).

\section{Survey}

A field survey was conducted among the Nicobar Islands in 2005-2010. The respondents were Nicobari tribes from different villages of Car Nicobar (Fig. 2), Katchal (Fig. 3), Nancowry (Fig. 4), Teressa (Fig. 5) and Kamorta (Fig. 6) islands. The data was collected using semi-structured forms and recorded from randomly selected tribes both through personal interviews and observations with relevant photographs. Among the Nicobarese the language spoken are Nicobari Language and they have adopted a form of Roman script for their language. However there are mild differences in Nicobari language spoken by Nicobarese of different islands. During survey we used Nicobari educated youth as enumerators (who speaks and understand Hindi language) to get better information about the subject during interaction.

\section{Nicobari tribes and their family organization}

\section{Results and discussion}

The Nicobarese, who are of advanced Mongoloid tribe with a large population of over 27,000. In general, with their attenuated Mongoloid characters (Fig. 2), the Nicobarese show resemblances more towards the Indonesian-Malays (5) which are further evident from geographical closeness of these islands towards South East Asian countries (Fig. 1). The Nicobarese live in a traditionally made hut (called as Nicobari hut) /shelters made in appropriate height from floor (Fig. 7). They are horticulturist and pig-herders inhabiting large permanent villages mostly close to sea shore. They are not divisible into tribes, but there are distinctions, chiefly territorial. Thus they may be fairly divided into six groups: the people of Car Nicobar, Chowra, and Teressa with Bompoka, the Central Group, the Southern Group and the single inland tribe of the Shompen on Great Nicobar. The term 'Nicobarese' refers to community of the indigenous people of Nicobar group of Islands, in general. It was given as a nomenclature to these people living in the Nicobar group of Islands and great Nicobar.

\section{Pigs of Nicobar islands}

Majority of the pigs appeared short with long body (Fig. 8). The pigs are healthy and active in nature. The skin colour of pig includes shades of red-brown, black, grey, brown, blackish brown and fawn. The bristles were dense, coarse with black or brown or creamy in colour. There was a marked bristle crest (mane) on the back of the pig extending from mid head/shoulder to base of the tail. There were no facial warts in pigs. These breeds were sturdy and short compared to other desi breeds. Head was short with a strong slightly curved (downward) snout. The pig's leg was short and they were fast runners. Tail was generally medium to long in size and the characteristic feature of the tail is that no curling observed and it was straight extending beyond hock. Most of the uncastrated pigs live inside the forest were heavy with well out grown tusk (upper and lower canine tooth), ferocious and tries to attack strange people. Other than local indigenous Nicobari pigs, Large White Yorkshire which was introduced by Animal Husbandry department also reared by Nicobari tribes in certain villages of Car Nicobar island. 


\section{Traditional pig rearing practices}

\section{Housing}

Pig rearing is very popular and custom among the Nicobari tribes and serves as an important source of animal protein (6). The Nicobari pigs natural habitat include rain forest, mountain forest and plantation area. The Nicobari pigs are reared under free range / scavenging system in the plantation/forest area and in Teressa Island also similar observation was made (6). On the contrary, scavenging system was observed in less than 1 per cent of pig rearers in North eastern tribal region (2). In Nicobar group of islands mostly, all the pigs are not staying at respective tribal house. The pigs roam freely and may or may not come to the residential area and they remain in the forest. Pigs were mainly resting undeneath the tribal's hut/ shelter (Fig. 9). The Nicobari hut/shelters were made in appropriate height from floor (approximately 2-3m) to provide sufficient space for pig to rest and to protect the pigs from heavy rainfall. Tribes also make bamboo cot (called as 'matchan' in Hindi) for resting, to dry supari/copra and to do kitchen work. They use and keep a long wooden made ladder to enter in to their hut and during evening/night hours before going to bed they remove the ladder and keep inside the house to prevent entry of any strange persons or animals inside their hut. A separate enclosure/shelters for piglet and rarely for adult were made using locally available material usually bamboos by the tribes of all the islands (Fig 10, 11 and 12). In Teressa Island, Nicobari tribes used sand as bedding material for adults and old rags, cloths or dry leaves as bedding material for new born piglets (6).

During 'Pig Festival' the pig own by the individual village is kept at village Captain's house in a well decorated arecanut enclosure. After a period of time the pig is slaughtered for consumption and pork is fed to the entire village through party among themselves.

\section{Feeding}

The Nicobari pigs are omnivorous; though largely vegetarian, they are opportunists and most will eat a wide range of food of animal origin including fish and marine life waste. All the tribal farmers allowed their pigs for free range / open grazing in the coconut plantation and inside the dense forest. The pigs were mainly fed with coconut by all the tribes (Fig. 14). In addition to it the pigs were also given little amount of kitchen waste viz. rice, wheat and vegetables (Fig. 16). Most of the tribes feed their group of pigs once daily in the evening. Prior to feeding, each tribe call their pigs by raising some sound (Fig.15) and the pigs reach exactly their hut/shelter/place of feeding in the forest area. Fresh coconuts are grated to different size according to the age group of pigs for feeding (Fig. 20).

Harvesting of fresh coconut is a regular practice every day and Nicobari tribal men climb over the coconut tree to harvest coconut using sickle. The harvested coconuts are accumulated below the tree and the 90 per cent of husk of individual coconut is removed and the left out husk is used for tying the coconuts together for easy transport and storage. The pigs are very fond of coconut and they really relish on the coconut feeding. Tribes break the coconuts and pour the water in the feeding utensils. Later the coconuts are grated in to small and large pieces using an indigenously made special knife made up of steel. Some time they keep the fresh coconut separately for feeding of pigs as and when needed. Both tribal men and women feed their pigs in group. The tribes sit on a raised wooden platform to feed pigs and approximately three to five coconuts are fed to each pig. After feeding, pigs usually go back into the forest. Other than routine raw coconut feeding, the pigs are fed with oil extracted (by an indigenous method) coconut powder (Fig. 18), waste of Pandanus fruit (locally called as Kevri) pulp (Fig. 19) and Nicobari alu (Fig. 21). Nicobari women involve in grating of coconut for oil extraction and tapioca (locally called Malayal alu) for cooking using a serrated stem of an indigenous plant called Kunheol in Nicobari language. The fish waste and waste generated out of coconut and tapioca grating is fed to pigs. The pig has good rooting behaviour and feeds on roots of wild palm, small insects, crabs and other sea wastes found in the sea shore. Similarly in Teressa Island pigs were fed with poor quality fish, snails and meaty portions of seashells (6). The feeding trough (Fig. 17) is locally called 'Naam' in Nicobari language which is made up of wood in different length $(30$ to $100 \mathrm{~cm}$ ) and width of $15-20 \mathrm{~cm}$. The big size bamboo stem are cut in two halves in the centre and in to different length for feeding. The empty hallow space is used for feeding. Other materials viz. old cans, shells of Giant clams (Tridacna spp.) and aluminium plates were used for feeding and watering. They do not prepare or cook any feed (ration) separately for feeding the pigs. However, they may still lack balanced nutrition (protein, energy and minerals etc.) and there is an urgent need for knowledge and technical know-how on resource driven feeding management for the tribes to improve the pig production system. 


\section{Pig rearing practices}

Pigs were allowed for open range feeding and the pig production system of Nicobari tribes is resource driven and mainly plantation based system. Pigs are fattened mainly on coconut feeding. On the contrary in Assam pig production is mainly based on family labour and feeds gathered or produced in household (2). In Mizoram, tribal communities dominate the state, accounting to more than $94 \%$ of the total population. Almost $100 \%$ of the tribal population was pork eaters and every household kept few pigs at backyard and irrespective of the pig breed, the pig farmers practiced low input production system, which was driven by the availability of local resources (7). Breeding in Nicobari pig occurs in the forest area by natural service. The breeding boar resides always in forest and it is very difficult to find or catch. The mature sow which goes inside the forest gets cross with boar. Tribal women take care of pregnant and nursing sows separately with extra care which is similar to traditional pig raising practices followed by people at Kebar, Manokwari where pregnant sows receive priority attention and as such are kept close to the dwellings and given good quality food and shelter (8). Pigs are considered as their family asset, they use pigs as a means of bartering among the community. Pigs are reared mainly for pork consumption among Nicobari tribes. Most of the festivals and ceremonies are centered on pig and the pig festival (Cana-haun in Nicobari language). During the festival Nicobari families select a grown up swine from their stock, slaughter and distribute it among themselves. Pigs are also slaughtered during various occasions like marriage ceremony and village mela. Another festival called as 'FATYA' in Nicobari language which is celebrated in memory of dead person. The pigs are also exchanged as gift between families and islands. This practice significantly contributes to avoidance of inbreeding among the pigs. No commercial system of pig rearing or sale of pork is prevailing among the Nicobari tribe. This could be due to the fact that the tribes are not a regular consumer of pork and they do not want their pig to be slaughtered regularly for meat purpose alone. In the last decade there was an out break of Swine Fever - a viral disease which caused mortality in young and adult pigs. Vaccination programme against Swine fever has been implemented by the department of Animal Husbandry. Incidence of parasitic diseases has also been reported. Other than this the tribes are not aware much about the common diseases and their incidence. This could be due to less attention paid/lack of knowledge of the tribal on pig disease and cause of mortality. Further, the tribes approach/seek veterinary assistance very rarely and in case of any unnatural death they rarely report to the Veterinary dept. for conducting post mortem \& further investigation. Other than diseases, the pigs are eaten away by the predators like Andaman Reticulated Python in the forest.

\section{Common terms, external and internal parts of pig in Nicobari Language}

The people of Car Nicobar have adopted a form of Roman Script for their language, called the Car Nicobarese script, is an Austro-Asiatic sub family language like Munda and Mon-Khmor languages once widespread in Burma and Malaysia (5). The common Nicobari terms/words used in relation to anatomical parts and pig rearing was recorded and given below with corresponding English words. There was mild variation in the script and pronounciation of Nicobari language between tribes of Nicobar group of islands.

\begin{tabular}{|c|c|}
\hline PARTS IN ENGLISH & $\begin{array}{c}\text { PARTS IN NICOBARI } \\
\text { LANGUAGE }\end{array}$ \\
\hline Pig & Ha-Un \\
\hline Male pig & Kōiny Ha-un \\
\hline Female pig & Kan Ha-un \\
\hline Piglet & Kun Ha-un \\
\hline Meat & Alaha \\
\hline Head & Kui \\
\hline Eye & Mat \\
\hline Fore head & Māl \\
\hline Ear & Naug \\
\hline Face & Arē kūö \\
\hline Nose & Elmeh \\
\hline Nostril & Rőngő Elmeh \\
\hline Ear & Nang \\
\hline Lips & Minuh \\
\hline Mouth & Elvāng \\
\hline Tongue & Hitak / Litak \\
\hline Teeth & Kanap \\
\hline Neck & Likeun \\
\hline Fore limb & Kēl \\
\hline Hind limb & Kalrőőn \\
\hline Thigh & Jakeun \\
\hline Shoulder & Elranôröö \\
\hline Stomach & Aich \\
\hline Finger & Kunti \\
\hline
\end{tabular}




\begin{tabular}{|c|c|}
\hline Chest & Elngō $\square \mathrm{h}$ \\
\hline Breast/Teat & Teh \\
\hline Jaw & Samā \\
\hline Knee & Kui kinmô $\square$ nő \\
\hline Feet & Kun rőőn \\
\hline Nail & Kinsòh \\
\hline Elbow & Sikòngk $\square 1$ \\
\hline Beard & Sanôikūő \\
\hline Back & Uk \\
\hline Tail & Làmrit \\
\hline Naval & Fun \\
\hline Skin & Uk alaha \\
\hline Fur & Sanôi alaha \\
\hline Brain & Tākā elkui \\
\hline Throat & El ki lőőp \\
\hline Ribs & Ranùmö \\
\hline Heart & Fanőinnylő \\
\hline Lungs & Alip \\
\hline Liver & Tilkup \\
\hline Pancreas & Tasalo \\
\hline Kidney & $\mathrm{N} \square \mathrm{m}$ hakőn \\
\hline Intestine & Puhū \\
\hline Anus & Kūőny $\square \square$ ch \\
\hline Nostril & Rőngő Elmeh \\
\hline Ear & Nang \\
\hline Lips & Minuh \\
\hline Mouth & Elvāng \\
\hline Tongue & Hitak / Litak \\
\hline Teeth & Kanap \\
\hline Neck & Likeun \\
\hline Blood & Maham \\
\hline Wound & Vahalaha \\
\hline Fracture & Lakool \\
\hline Medicine & Lane-en \\
\hline Injection & Lanock \\
\hline Fever & Veui \\
\hline Testes & Kuloich \\
\hline Ovary & El Haun \\
\hline Udder & Chuok-Teh \\
\hline Castration & Talliyo \\
\hline Gestation & Puyosa \\
\hline Parturition & Am Ko ti el \\
\hline
\end{tabular}

\section{Conclusion}

Pig rearing has a specialized significance as it can play an important role in improving the cultural and socio-economic status of tribal population. It gives nutritional security and safeguard to the crop failures in the event of natural calamities. This unique indigenous pig germplasm is considered as prosperity of Nicobari tribes belonging to this island territory and their existence was noted since many centuries. These breeds are well adapted to the island ecosystem over the centuries and performing well under the integrated resource-driven (plantation based) production system. The Nicobari pigs are reared and considered as family asset among the tribes. The Nicobari pigs are under constant threat due to natural calamities (earth quake, tsunami), outbreak of disease (swine fever), predators (Reticulated pythons) and lack of scientific breeding and farming practices. There is an urgent need to formulate conservation strategies for the farming system management, genetic improvement and conservation.

\section{Acknowledgement}

The authors are grateful to INDIAN COUNCIL OF AGRICULTURAL RESEARCH Govt. of India, for providing necessary facilities under the AP Cess funded project on "Conservation and characterization of Nicobari pig" to carry out the study, the Director, Central Island Agricultural Research Institute, Port Blair, , Director, Senior Veterinary Officers and Para-veterinary staff of Department of Animal Husbandry and Veterinary Services, Project staff of Nicobari pig project, Tribes and Tribal Council, Nicobar islands for providing necessary facilities and assistance to carry out the study. 


\section{References}

[1]. Anonymus. 2011. Independence Day : Special Supplement, The Daily Telegrams, Monday, August 15, $2011, \mathrm{p} 8$.

[2]. Deka R, Thorpe W, Lapar ML and Kumar A. 2007. Kokrajhar's pig sub-sector: Current status, constraints and opportunities, In: Project Report: International Livestock Research Institute CG Block, NASC Complex, DPS Marg, Pusa Campus, New Delhi110012, India.

[3]. Ramakrishna, Ragunathan C and Sivaperuman C. 2010. Chapter 01. Biodiversity of Andaman and Nicobar Islands-An overview, In: Recent Trends in Biodiversity of Andaman and Nicobar Islands, edited by Ramakrishna, Ragunathan C \& Sivaperuman C, Published by the Director, (Zoological Survey of India, Kolkata), 2010, 1-42.

[4]. Jeyakuamar, S. and Jai Sunder. 2010 Conservation and characterization of Nicobari pig, In: Project Report, Central Agricultural Research Institute, Port Blair, India, 2010.

[5]. Verma, C., Bhatia, S., and Srivastava S. 2010. Traditional medicine of the Nicobarese, Indian J Traditional Knowledge, 9 (4) : 779785 .

[6]. Srivastava, N., Ahlawat S.P.S., Chatterjee R.N., Roy, M.M., Choudhuri, N.C. and Saha S.K. 2002. Backyard swine rearing practices among Nicobari tribes of Andaman and Nicobar Islands, Indian J. Anim. Hlth., 41 (1) : 9-12.

[7]. Kumaresan, A., Bujarbaruah, K.M., Pathak, K.A., Anubrata Das and Bardoloi, R.K. 2009. Integrated resource-driven pig production systems in a mountainous area of Northeast India: production practices and pig performance, Trop Anim Health Prod. 41: 11871196.

[8]. Pattiselanno F, Traditional pig rising at Kebar, Manokwari, Suiform Soundings PHSG Newsletter Vol. 4 (1): 19-20(2004).

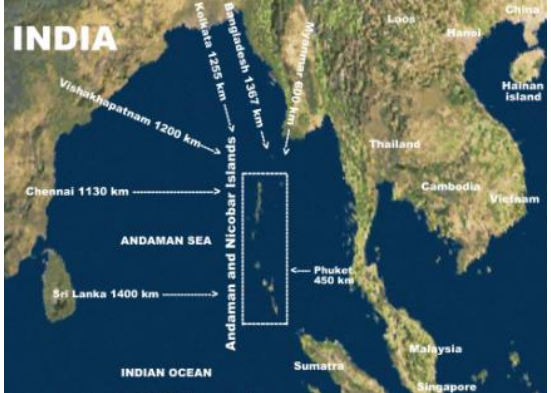

Fig. 1 Andaman and Nicobar islands with neighbouring countries

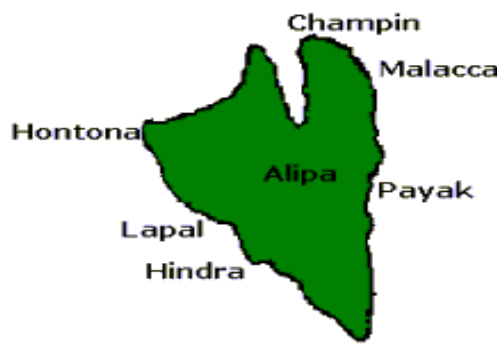

Fig. 4 Nancowrie island

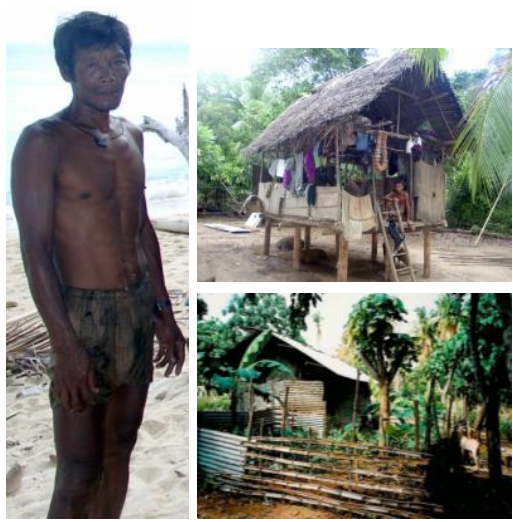

Fig. 7 A Nicobari tribe and their traditional Shelter with home garden at Car Niocbar and Teressa island

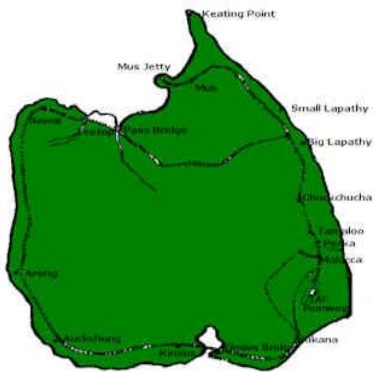

Fig.2 Car Nicobar island

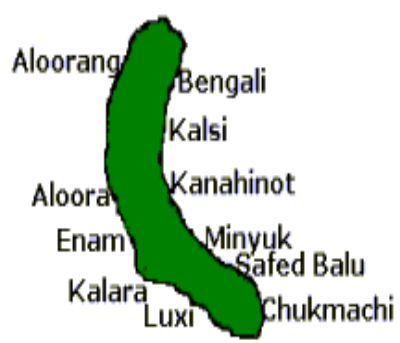

Fig. 5 Teressa island

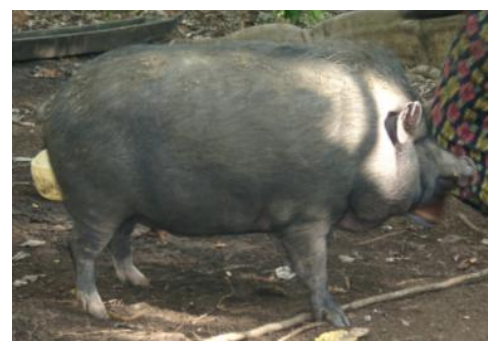

Fig. 8 Adult Nicobari pig

Fig. 9 Shelter for pig beneath hut
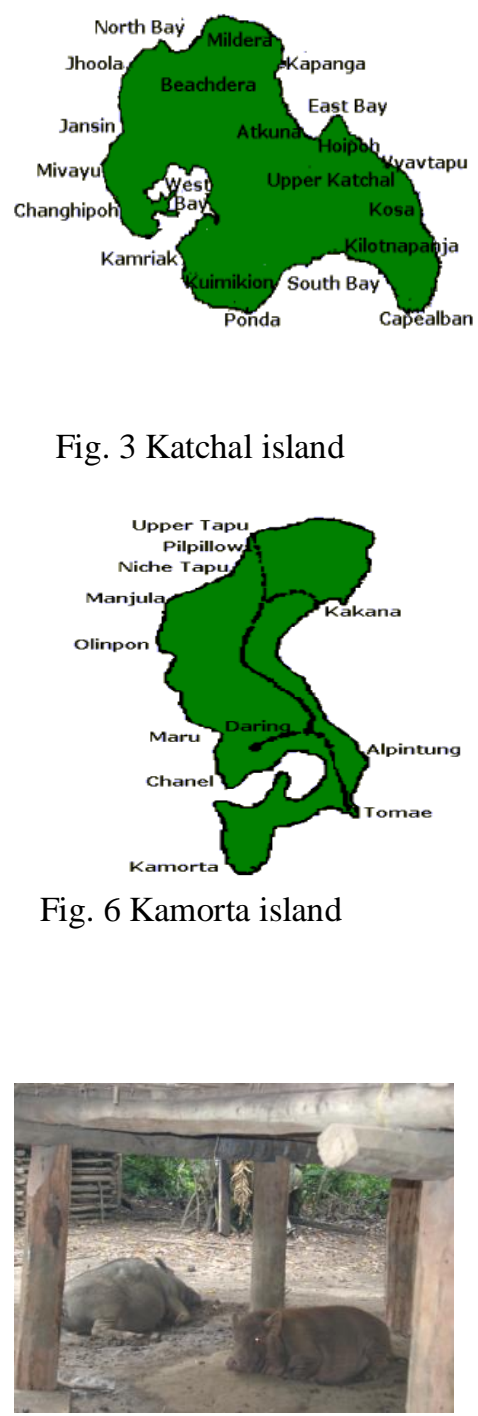

Fig. 3 Katchal island

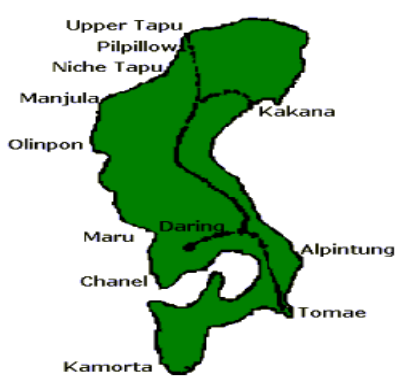

Fig. 6 Kamorta island 


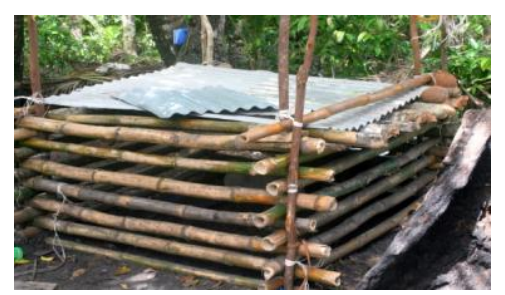

Fig. 10 Bamboo shelter for piglets

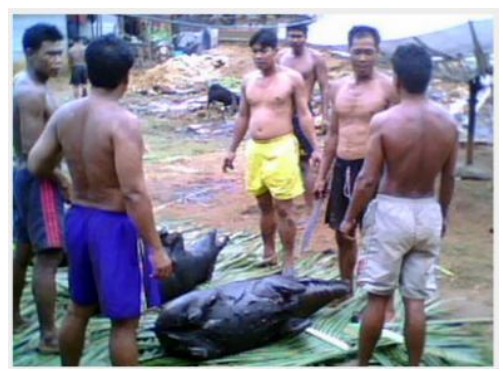

Fig. 13 Pig slaughter and dressing

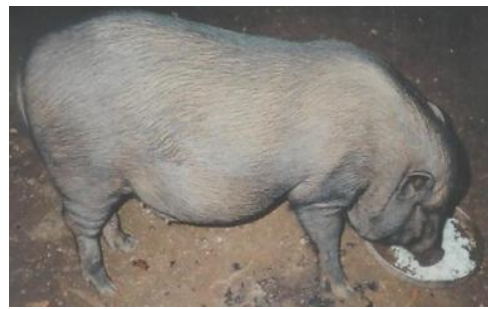

Fig. 16 Pig feeding on kitchen waste

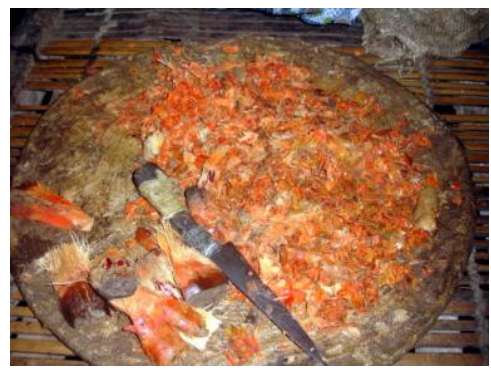

Fig. 19 Pandanus fruit waste as feed Fig. 20 Fresh coconut slices for pig

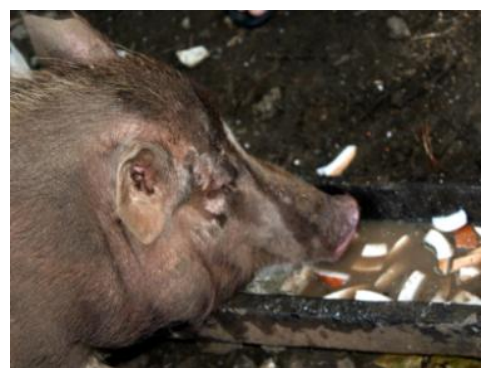

Fig. 14 Pig feeding on coconut

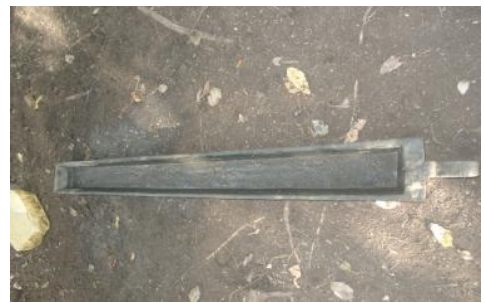

Fig. 17 Pig feeder (naam)

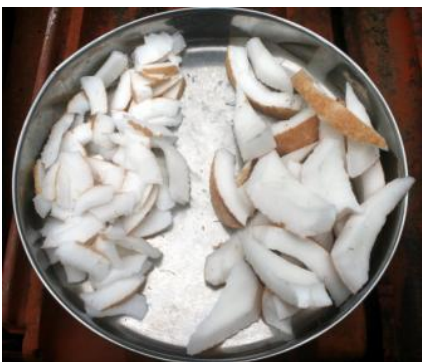

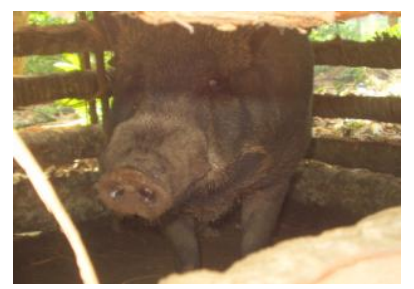

Fig. 12 Wooden cage for adult pig

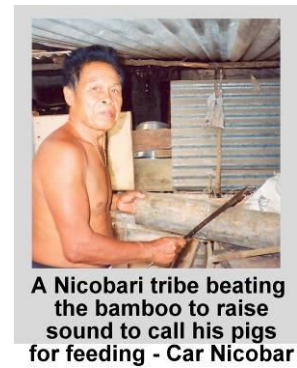

Fig. 15 Tribe raising a sound to call pigs

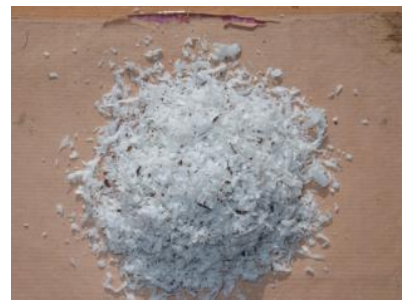

Fig. 18 Oil extracted coconut as pig feed

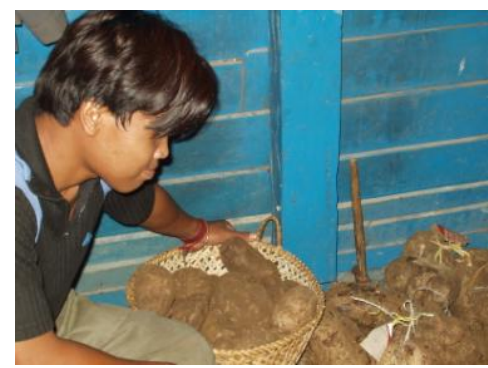

Fig. 21 Nicobari alu as pig feed 